\title{
TRIFLURALIN: WEED CONTROL IN PEAS
}

\author{
R. TAYLOR AND R. N. ARnst \\ Imperial Chemical Industries (N.Z.) Ltd., Christchurch
}

\section{Summary.}

Trifluralin at $1.0 \mathrm{lb} /$ acre incorporated with soil before planting, adequately controlled weeds, mainly fathen (Chenopodium album) and spurrey (Spergula arvensis) in peas: the yield of peas following treatment at this rate was $25 \%$ greater than the yield of peas treated with MCPB and $47 \%$ greater than untreated peas. Trifluralin at $2.0 \mathrm{lb}$ depressed the yield of peas and shepherd's purse (Capsella bursa-pastoris) was only partially checked by trifluralin at this rate.

\section{INTRODUCTION}

Problems in the use of dinoseb and MCPB for weed control in peas have been described and the results of trials with prometryne and linuron reported (Duff and Moffat, 1965; Smith and Dow, 1966). Trifluralin, a soil-incorporated herbicide, can be used for weed control in peas and has the advantage of controlling weeds during the early stages of crop growth. A trial was therefore carried out to measure weed control effects and crop tolerance under South Island conditions.

\section{METHODS}

The trial was laid down on a Hatfield silt loam in Canterbury. Trifluralin at $0.5,1.5$ and $2.0 \mathrm{lb} /$ acre was applied on October 5,1968 , in $25 \mathrm{gal} / \mathrm{acre}$ and all plots rotavated to a depth of about $3 \mathrm{in}$. within one hour following application. Peas (variety Jade) were drilled later the same day.

Treatments were applied to plots, $15 \times 210 \mathrm{ft}$, and arranged in randomized blocks with four replicates. MCPB $(1.0 \mathrm{lb} /$ acre $)$ was applied after crop emergence on December 3, 1968. Untreated plots were windrowed three days before threshing to reduce problems with green fathen plants (Chenopodium album). An area of $10 \times 210 \mathrm{ft}$ within each plot was harvested on February 24, 1969. Weed seeds, mainly fathen, were separated and the peas weighed: results were calculated in bushels per acre at $16 \%$ moisture content $(1 \mathrm{bu}$ of peas $=60 \mathrm{lb})$. Germination tests were carried out on sub-samples from two blocks of the trial.

\section{RESULTS AND DISCUSSION}

The main weeds affecting growth in untreated plots were fathen, spurrey (Spergula arvensis), shepherd's purse (Capsella bursa-pastoris) wireweed (Polygonum aviculare) and tares (Vicia sp.) with some patches of Californian thistle (Cirsium arvense): fathen was the main weed affecting yield.

MCPB suppressed fathen and shepherd's purse but other weeds were relatively unaffected. Trifluralin controlled fathen and spurrey but shepherd's purse and tares were resistant.

Yields and percentage germination are as given in Table 1. 
TABLE 1: YIELDS AND \% GERMINATION OF PEAS

\begin{tabular}{lccc}
\hline $\begin{array}{c}\text { Treatment } \\
\text { (lb a.i./acre) }\end{array}$ & $\begin{array}{c}\text { Yield } \\
\text { (bu/acre) }\end{array}$ & $\begin{array}{c}\text { Relative } \\
\text { Yield }\end{array}$ & $\begin{array}{c}\text { \% Germination } \\
\text { (Mean of 2 samples) }\end{array}$ \\
\hline Unsprayed & $18.7 \mathrm{cC}$ & 100 & 93 \\
MCPB 1.0 & $22.8 \mathrm{bB}$ & 122 & 95 \\
trifluralin 0.5 & $23.5 \mathrm{bB}$ & 126 & 95 \\
trifluralin 1.0 & $27.4 \mathrm{aA}$ & 147 & 95 \\
trifluralin 2.0 & $23.3 \mathrm{bB}$ & 125 & 98 \\
\hline
\end{tabular}

Trifluralin at $1.0 \mathrm{lb}$ gave the highest yield of dressed peas, almost $9 \mathrm{bu}$ or $47 \%$ more than the untreated control and $4.6 \mathrm{bu}$ more than peas treated with MCPB. At 0.5 and $1.5 \mathrm{lb}$ trifluralin per acre the yield of peas did not differ significantly from MCPB at $1.0 \mathrm{lb}$. At the highest rate $(2.0 \mathrm{lb})$ trifluralin caused a slight depression in yield. Germination was not affected by any treatment.

\section{ACKNOWLEDGEMENT}

The authors wish to thank D. C. McCausland for the provision of the trial site and assistance in laying down and harvesting the trial.

\section{REFERENCES}

Duff, G. B.; Moffat, R. W., 1965: Proc. 18th N.Z. Weed \& Pest Control Conf.: 54.

Smith, A. H.; Dow, D. R. H., 1966: Proc. 19th N.Z. Weed \& Pest Control Conf.: 60 . 